\title{
Pengaruh Rasio Campuran Napthalene pada Premium terhadap Efisiensi Bahan Bakar dan Kinerja Mesin Sepeda Motor 4tak
}

\author{
Fogot Endro Wibowo ${ }^{1}$, dan Fauzhia Rahmasari ${ }^{2}$ ) \\ ${ }^{1,2}$ Teknik Mesin, Fakultas Teknologi Industri, Universitas Jayabaya, Jakarta, Indonesia \\ Email: fogotendro@jayabaya.ac.id ${ }^{1}$, fauzhiarahmasari@jayabaya.ac.id²
}

Received 8 Juli $2021 \mid$ Revised 12 Juli 2021 | Accepted 21 Juli 2021

\begin{abstract}
ABSTRAK
Pemerintah Indonesia berharap kualitas baik dari gas buang kendaraan khususnya sepeda motor, diperlukan bahan bakar kualitas tinggi yaitu bahan bakar dengan nilai oktan tinggi. Napthalene adalah senyawa hidrokarbon dengan rumus kimia $\mathrm{C}_{10} \mathrm{H}_{16} \mathrm{O}$. Struktur kimia yang mirip bensin, memiliki rantai lebih panjang membuat Napthalene diduga dapat meningkatkan nilai oktan bensin. Tujuan penelitian yaitu menganalisis pengaruh rasio pencampuran Napthalene pada premium terhadap konsumsi bahan bakar $(\mathrm{km} / \mathrm{l})$ dan peningkatan kinerja pada mesin sepeda motor bebek jenis manual $110 \mathrm{cc}$ dan $115 \mathrm{cc}$. Metodenya adalah eksperimen. Parameternya yaitu tingkat efisiensi konsumsi premium $(\mathrm{km} / \mathrm{l})$, peningkatan kinerja meliputi torsi dan daya (Horse Power) pada motor jenis tersebut. Rasio perbandingan Napthalene dan premium yaitu $3 \mathrm{gram} / \mathrm{l}, 6 \mathrm{gram} / \mathrm{l}$ dan $9 \mathrm{gram} / \mathrm{l}$. Hasil uji menunjukkan rasio pencampuran Napthalene pada premium sebanyak 9 gram/l merupakan yang paling berpengaruh terhadap tingkat efisiensi konsumsi premium dan kinerja mesin pada kedua jenis motor tersebut. Aplikasi tersebut tentunya akan memperbaiki kualitas gas buang.
\end{abstract}

Kata kunci : efisiensi, premium, naphthalene, nilai oktan

\begin{abstract}
The Indonesian government hopes that the good quality of vehicle exhaust gases, especially motorcycles, requires high quality fuel, namely fuel with a high octane rating. Napthalene is a hydrocarbon compound with the chemical formula $\mathrm{C1OH16O}$. The chemical structure is similar to gasoline, having a longer chain makes Napthalene allegedly able to increase the octane value of gasoline. The purpose of the study was to analyze the effect of the Napthalene mixing ratio at premium on fuel consumption $(\mathrm{km} / \mathrm{l})$ and performance improvement on the $110 \mathrm{cc}$ and $115 \mathrm{cc}$ manual motorcycle engines. The method is experimental. The parameters are the level of premium consumption efficiency $(\mathrm{km} / \mathrm{l})$, increased performance including torque and power (Horse Power) on this type of motorcycles. The ratio of Napthalene and premium is 3 grams/l, 6 grams/l and 9 grams/l. The test results show that the Napthalene mixing ratio at premium as much as 9 grams/l is the most influential on the level of premium consumption efficiency and engine performance on both types of motorcycles. The application will certainly improve the quality of exhaust gas.
\end{abstract}

Keywords: efficiency, premium, naphthalene, octane rating 


\section{PENDAHULUAN}

Laju pertumbuhan kendaraan bermotor menunjukkan kuantitas peningkatan setiap tahunnya. Data Badan Pusat Statistik (BPS) mencatat bahwa pertumbuhan kepemilikan kendaraan bermotor di Indonesia sejak tahun 2009 hingga 2018 meningkat sebesar 9,05\% [1]. Jumlah kendaraan bermotor pada tahun 2018 mencapai 146.858 .759 unit. Rasio peningkatan kendaraan bermotor mayoritas didominasi jenis sepeda motor sebesar $81,8 \%$. Untuk wilayah JABODETABEK sendiri pertumbuhan jumlah kendaraan bermotor sangat tinggi dalam kurun waktu sepuluh tahun terakhir yaitu sebesar $15,7 \%$ [2]. Tingginya laju peningkatan kendaraan bermotor tersebut berbanding lurus dengan laju konsumsi bensin sebagai sumber bahan bakar.

Premium sebagai salah satu contoh bahan bakar minyak dengan karakteristik nilai oktan 88 merupakan yang paling populer digunakan di Indonesia khususnya dalam bidang transportasi karena harganya yang relatif murah. Konsumsi bahan bakar premium sendiri menunjukkan angka permintaan yang cukup tinggi dibanding jenis bahan bakar minyak lainnya khususnya untuk pemilik kendaran roda dua. Sebuah studi menunjukkan bahwa konsumsi premium di Jakarta pada tahun 2013 mencapai 6 juta liter perhari sedangkan konsumsi nasional mencapai 80 juta liter perhari [3]. Tingginya permintaan bahan bakar premium tentu tidak berbanding lurus dengan persediaannya yang justru semakin menurun. Sampai saat ini potensi minyak bumi di Indonesia hanya 43,7 miliar barel yang artinya cadangan minyak di Indonesia hanya cukup dan akan bertahan dalam kurun waktu kurang lebih 10 tahun lagi serta di pasar internasional juga dikurangi peredarannya. Dan ada efek lain dari banyaknya pemakaian premium ini, yaitu karena nilai oktan dari premium ini rendah maka emisi gas karbon juga meningkat. Padahal pemerintah ingin menjalankan kesepakatan standar EURO 4 yang dituangkan dalam Peraturan Menteri Lingkungan Hidup dan Kehutanan Nomor 20 tahun 2017 mengenai batasan Research Octane Number (RON). Sesuai standar EURO 4, bahwa besaran RON minimal adalah 91. Dengan besaran RON yang tinggi akan meningkatkan kinerja mesin menjadi lebih sempurna, kompresi mesin menjadi lebih tinggi dan akselerasi menjadi lebih bagus. Yang pada akhirnya kualitas gas buang dari kendaraan akan lebih baik.

Untuk mengantisipasi keadaan tersebut perlu dilakukan sebuah inovasi yang memberikan solusi dalam upaya menghemat penggunaan BBM khususnya bahan bakar premium serta kualitas gas buang tanpa menurunkan performa tenaga kendaraan atau merusak mesin seperti timbulnya knocking atau letupan. Beberapa kajian telah menyebutkan untuk meningkatkan performa kendaraan dan mengurangi terjadinya knocking dapat dilakukan dengan cara meningkatkan nilai oktan bahan bakar yang digunakan [4]. Peningkatan nilai oktan dapat dilakukan dengan cara mencampurkan bahan bakar utama dengan bahan bakar lain yang memiliki nilai oktan yang lebih tinggi [5][6] atau dengan menambahkan bahan aditif seperti contohnya Napthalene [7]. Napthalene atau lebih populer dikenal dengan nama kamper atau kapur barus merupakan senyawa hidrokarbon dengan rumus kimia $\mathrm{C}_{10} \mathrm{H}_{16} \mathrm{O}$ (Gambar 1). Dengan struktur kimia yang mirip dengan bensin dan memiliki rantai $\mathrm{C}$ yang lebih panjang, membuat Napthalene diduga dapat meningkatkan nilai oktan bensin. Sehingga proses pembakaran yang dihasilkan semakin sempurna dan mengurangi terjadinya proses knocking. Beberapa studi membuktikan bahwa zat Napthalene yang terdapat pada kapur barus dapat meningkatkan performa mesin motor bebek [7][8] dan mesin mobil [9] serta memiliki pengaruh terhadap gas buang yang dihasilkan. 


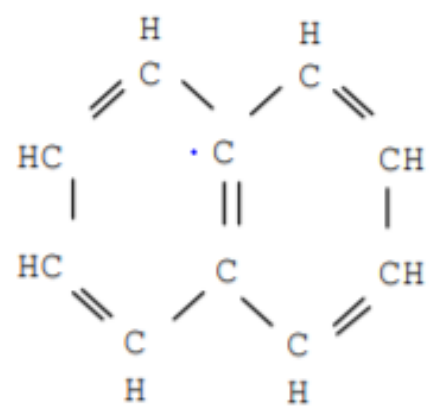

Gambar 1. Struktur kimia senyawa napthalene

Tujuan penelitian ini yaitu menganalisis pengaruh rasio pencampuran Napthalene pada bahan bakar premium terhadap konsumsi bahan bakar $(\mathrm{Km} / \mathrm{L})$ dan peningkatan kinerja pada mesin sepeda motor bebek 4tak jenis manual $110 \mathrm{cc}$ dan sepeda motor bebek 4tak jenis manual $115 \mathrm{cc}$. Jenis sepeda motor dan besaran cc tersebut kita pilih dikarenakan jumlah penggunanya yang masih tinggi di Indonesia. Penelitian ini diharapkan dapat memberikan manfaat berupa informasi mengenai Napthalene sebagai bahan aditif pada bahan bakar premium. Selain itu, diperoleh juga informasi mengenai data persentase penghematan konsumsi bahan bakar premium sekaligus efek yang ditimbulkan terhadap meningkatkan kinerja mesin meliputi torsi dan daya kuda (Horse Power) pada sepeda motor bebek 4tak jenis manual $110 \mathrm{cc}$ dan sepeda motor bebek 4 tak jenis manual $115 \mathrm{cc}$.

\section{METODE PENELITIAN}

\subsection{Alat dan Bahan}

Alat yang digunakan pada penelitian ini antara lain yaitu 2 unit sepeda motor bebek 4tak jenis manual dengan mesin $110 \mathrm{cc}$ dan sepeda motor bebek 4tak jenis manual dengan mesin $115 \mathrm{cc}$ sebagai media uji aplikasi. Kedua jenis motor tersbut tidak menggunakan katalis serta umur dan lama pakai yang tidak berbeda jauh, serta asumsi driving cycle yang sama. Selain itu digunakan alat Chasis Dynamometer (gambar 2) lengkap terhubung dengan satu unit komputer untuk mendapatkan data torsi dan daya kuda (Horse Power) dari suatu mesin. Alat tersebut digunakan untuk Dyno Test. Dan juga digunakan kunci pas, obeng, kunci L, gelas ukur, timbangan analitik, mortar serta dispenser bensin. Bahan yang digunakan dalam penelitian ini adalah bensin jenis premium dan Napthalene dalam bentuk serbuk.
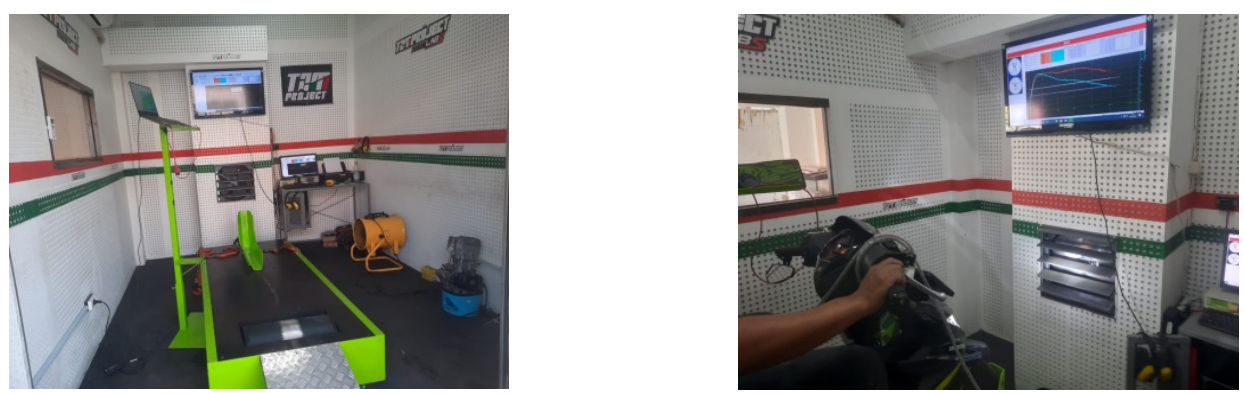

Gambar 2. Chasis Dynamometer

\subsection{Metode}

Penelitian ini dilakukan dengan metode eksperimen yang bertempat di bengkel Bintang Racing Team PT. Tri Mentari Niaga Sentul, Bogor. Parameter utama yang menjadi kajian dalam penelitian ini yaitu pengaruh rasio Napthalene terhadap konsumsi pemakaian bahan bakar premium $(\mathrm{Km} / \mathrm{L})$ dan peningkatan tenaga meliputi torsi dan daya kuda (Horse Power) pada sepeda motor bebek 4tak jenis manual $110 \mathrm{cc}$ dan sepeda motor bebek 4tak jenis manual $115 \mathrm{cc}$. Metode eksperimen ini menggunakan 
rasio perbandingan antara Napthalene dan bahan bakar jenis premium yang digunakan terdiri dari 3(tiga) rasio yaitu 3 gram/L, 6 gram/L dan 9 gram/L (gambar 3).

\subsection{Prosedur Penelitian}

\section{a. Preparasi dan penambahan serbuk Napthalene pada premium [7][8]}

Sebanyak 250 gram Napthalene digerus menggunakan mortar hingga halus. Supaya berbentuk serbuk halus, maka Napthalene yang telah digerus kemudian disaring menggunakan saringan 50 mash. Selanjutnya serbuk Napthalene yang sudah berbentuk serbuk halus ditambahkan ke dalam bahan bakar premium yang akan di uji sesuai rancangan penelitian yaitu dengan rasio perbandingan $3 \mathrm{gram} / \mathrm{L}, 6$ gram/L dan 9 gram/L. Setelah tercampur dilakukan pengadukan selama \pm 15 menit agar Napthalene terlarut sempurna.

\section{b. Prosedur pengujian efisensi konsumsi premium [7]}

Pengujian efisensi konsumsi premium dilakukan dengan cara menguji campuran Napthalene pada bahan bakar premium dengan yang rasio yang telah ditentukan. Selanjutnya dilakukan uji aplikasi pada sampel sepeda motor uji (motor jenis bebek 4tak jenis manual $110 \mathrm{cc}$ dan sepeda motor bebek 4 tak jenis manual $115 \mathrm{cc}$ ). Kemudian dihitung jarak dalam km yang dapat ditempuh untuk setiap satu Liter rasio perlakuan uji.

\section{c. Prosedur pengujian torsi dan daya [8]}

Pengujian torsi dan daya dapat dilakukan dengan dynotest menggunakan alat chasis dynamometer. Langkah-langkah menguji kendaraan dengan memakai alat ini, meliputi beberapa tahapan. Tahapan awal yang dilakukan terlebih dahulu menyiapkan kendaraan uji lalu melepaskan cover body bagian main pipe cover. Setelah itu, sepeda motor dinaikkan ke atas chasis dynamometer, mengatur stoper roda depan dengan mengikat sepeda motor pada chasis dynamometer dengan menggunakan tie down serta memasang kabel sensor putaran mesin pada input koil pengapian.

Selanjutnya mengisi bahan bakar pengujian, lalu menyalakan mesin dilanjutkan menghidupkan mesin selama ( \pm 3 menit) sehingga mendekati suhu kerja mesin, serta menghidupkan blower. Setelah semua persiapan selesai, gas akan membuka throttle valve sampai mesin menunjukkan putaran yang diinginkan dan mesin chasis dynamometer mulai membaca daya dan torsi mesin.

Berikutnya menyimpan data pengukuran daya dan torsi lalu mencetak hasil pengujian berbentuk grafik jika diperlukan, kemudian mematikan mesin. Setelah selesai dilanjutkan menguras bahan bakar premium sampai habis termasuk bahan bakar yang tersisa di karburator. Prosedur yang sama dilakukan untuk menguji rasio jenis bahan bakar yang berbeda dan sampel uji motor berikutnya.

\section{d. Analisis data}

Hasil pengujian efisiensi dan pengukuran daya serta torsi yang diperoleh selanjutnya diolah dalam bentuk grafik dan tabel. Data tersebut dideskripsikan menggunakan teknik deskriptif kuantitatif. 


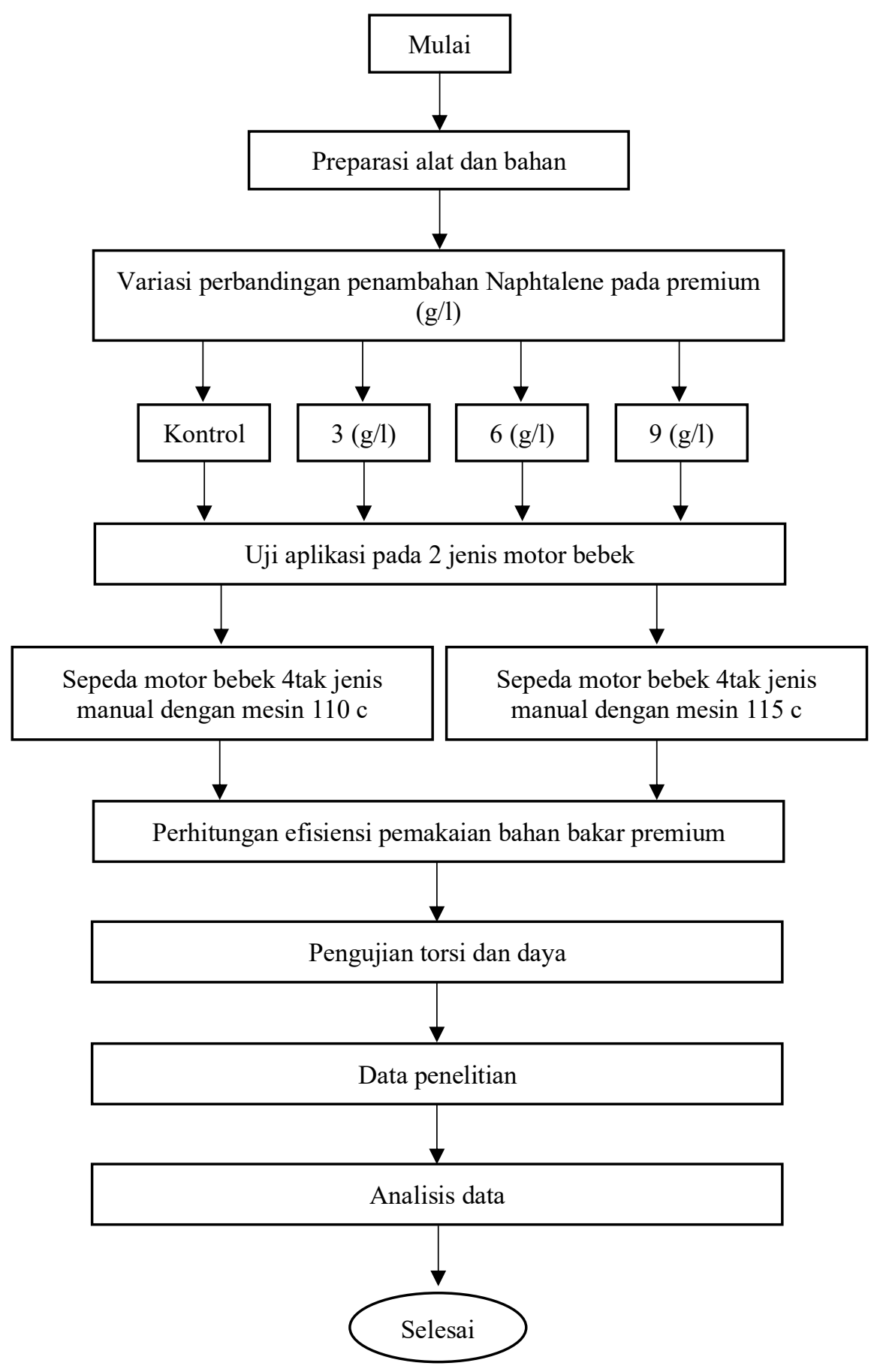

Gambar 3. Bagan alir penelitian

\section{HASIL DAN PEMBAHASAN}

Variasi rasio perbandingan penggunaan Napthalene sebagai aditif pada bahan bakar premium bertujuan untuk menganalisis tingkat efektifitas Napthalene dalam meningkatkan persentase efisiensi penggunaan bahan bakar premium persatuan gram Napthalene yang ditambahkan ke dalam bahan bakar premium tersebut. Perlakuan penambahan Napthalene dilakukan secara bertingkat dari rasio perbandingan sebesar 3 gram/L, kemudian sebesar 6 gram/L, dan selanjutnya sebesar 9 gram $/ \mathrm{L}$. 
Terdapat kontrol atau standard yaitu pemakaian bahan bakar premium tanpa dilakukan penambahan Napthalene yang bertujuan sebagai nilai pembanding awal. Uji aplikasi konsumsi bahan bakar dilakukan pada jenis mesin sepeda motor bebek 4tak jenis manual $110 \mathrm{cc}$ dan sepeda motor bebek 4tak jenis manual $115 \mathrm{cc}$. Hal ini bertujuan untuk memberikan gambaran tingkat efisiensi pada jenis mesin sepeda motor bebek 4tak yang berbeda dan sebagai rujukan aplikasi yang tepat penggunaan Napthalene sebagai aditif bahan bakar dalam hal ini khususnya bahan bakar premium.

Tingkat konsumsi bahan bakar spesifik merupakan suatu parameter prestasi yang dipakai sebagai ukuran ekonomi pemakaian bahan bakar yang terpakai perjam untuk setiap daya kuda yang dihasilkan [11]. Selain itu terdapat juga faktor efisiensi yang merupakan nilai perbandingan antara daya yang dihasilkan per siklus terhadap jumlah energi yang disuplai per siklus yang dapat dilepaskan selama pembakaran [12]. Sehingga kedua parameter ini sangat penting untuk diperhatikan pada awal penelitian.

Tabel 1. Efisiensi konsumsi bahan bakar premium pada sepeda motor bebek 4tak jenis manual 110 cc

\begin{tabular}{ccc}
\hline Perlakuan $($ gram $/ \mathrm{L})$ & Konsumsi premium $(\mathrm{Km} / \mathrm{L})$ & Efisiensi $(\%)$ \\
\hline Kontrol & 39 & 7.6 \\
3 & 42,2 & 8,2 \\
6 & 47,5 & 22 \\
9 & 48,75 & 25 \\
\hline
\end{tabular}

Dari tabel 1 terlihat bahwa konsumsi bahan bakar premium di sepeda motor bebek 4tak jenis manual $110 \mathrm{cc}$, pada perlakuan kontrol, memberikan nilai konsumsi bahan bakar premium sebesar $39 \mathrm{Km} / \mathrm{L}$ dengan nilai efisiensi sebesar 7.6\%. Pada perlakuan dengan rasio Napthalene sebanyak $3 \mathrm{gram} / \mathrm{L}$ memberikan nilai konsumsi bahan bakar premium sebesar $42,2 \mathrm{Km} / \mathrm{L}$ dengan nilai efisiensi sebesar $8,2 \%$. Dan perlakuan dengan rasio Napthalene sebanyak 6 gram/L memberikan nilai konsumsi bahan bakar premium sebesar $47,5 \mathrm{Km} / \mathrm{L}$ dengan nilai efisiensi sebesar $22 \%$. Sedangkan perlakuan dengan rasio Napthalene sebanyak 9 gram/L memberikan nilai konsumsi bahan bakar premium sebesar 48,75 $\mathrm{Km} / \mathrm{L}$ dengan nilai efisiensi sebesar $25 \%$.

Perlakuan dengan rasio Napthalene sebanyak 9 gram/L memberikan pengaruh terbaik pada parameter tingkat presentase efisiensi penggunaan premium sebagai bahan bakar pada mesin sepeda motor bebek 4tak jenis manual $110 \mathrm{cc}$ (Gambar 3). Rasio penggunaan Napthalene 9 gram/L memberikan nilai konsumsi bahan bakar premium sebesar $48,75 \mathrm{~km} / \mathrm{L}$ dengan nilai efisiensi $25 \%$. Nilai tersebut lebih tinggi dibandingkan rasio perlakuan lain, yaitu pada perlakuan dengan rasio Napthalene sebanyak 3 gram/L dan 6 gram/L, serta perlakuan kontrol.

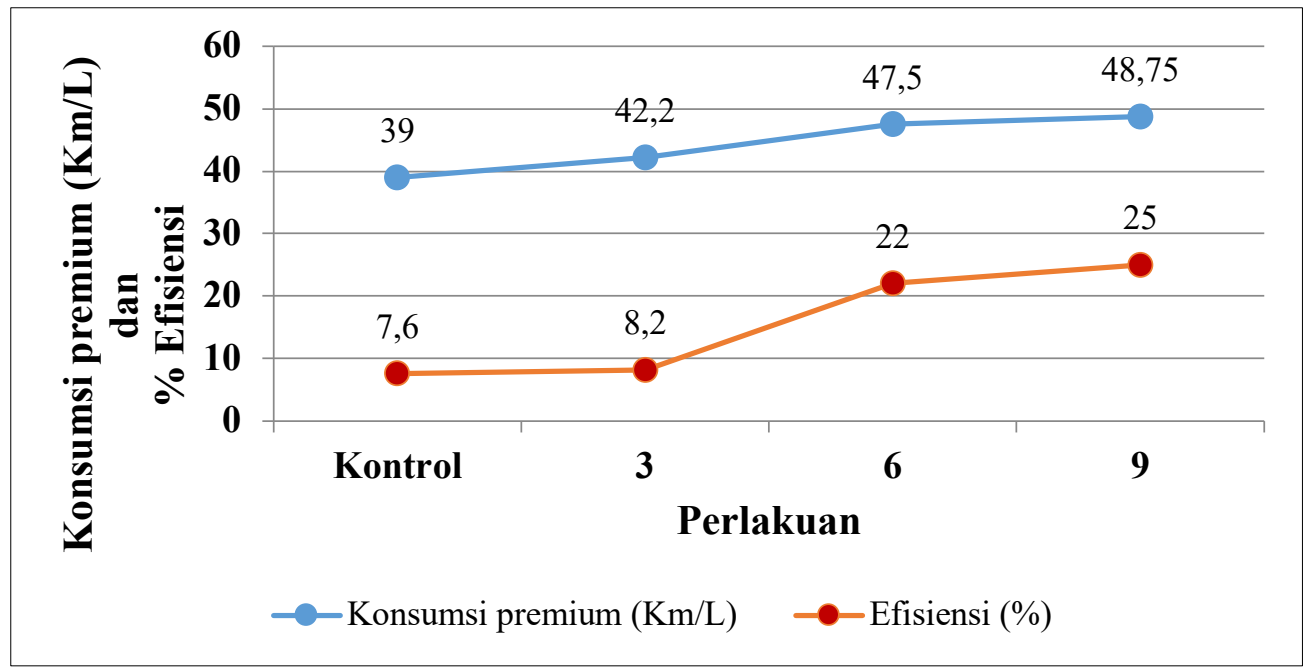

Gambar 4. Persentase efisiensi konsumsi bahan bakar premium pada sepeda motor bebek 4tak jenis manual $110 \mathrm{cc}$

Rekayasa Hijau - 119 
Fogot Endro Wibowo, dan Fauzhia Rahmasari

Tabel 2. Efisiensi konsumsi bahan bakar premium pada sepeda motor bebek 4tak jenis manual 115 cc

\begin{tabular}{ccc}
\hline Perlakuan $($ gram $/ \mathrm{L})$ & Konsumsi premium $(\mathrm{Km} / \mathrm{L})$ & Efisiensi $(\%)$ \\
\hline Kontrol & 39 & 11 \\
3 & 43,3 & 12 \\
6 & 48,75 & 25 \\
9 & 55,7 & 42 \\
\hline
\end{tabular}

Dari tabel 2 terlihat bahwa konsumsi bahan bakar premium pada sepeda motor bebek 4 tak jenis manual $115 \mathrm{cc}$, perlakuan kontrol, memberikan nilai konsumsi bahan bakar premium sebesar $39 \mathrm{Km} / \mathrm{L}$ dengan nilai efisiensi sebesar $0 \%$. Sedangkan pada perlakuan dengan rasio perbandingan Napthalene sebanyak 3 gram/L memberikan nilai konsumsi bahan bakar premium sebesar $43,3 \mathrm{Km} / \mathrm{L}$ dengan nilai efisiensi sebesar 12\%. Dan perlakuan dengan rasio perbandingan Napthalene sebanyak 6 gram/L memberikan nilai konsumsi bahan bakar premium sebesar $48,75 \mathrm{Km} / \mathrm{L}$ dengan nilai efisiensi sebesar $25 \%$. Selanjutnya pada perlakuan dengan rasio perbandingan Napthalene sebanyak 9 gram/L memberikan nilai konsumsi bahan bakar premium sebesar $55,7 \mathrm{Km} / \mathrm{L}$ dengan nilai efisiensi sebesar $42 \%$.

Hasil pengujian pada mesin motor bebek jenis manual 115cc (Gambar 4) serupa terjadi pada pengujian mesin motor bebek jenis manual $110 \mathrm{cc}$. Napthalene 9 gram/l memberikan nilai konsumsi bahan bakar premium sebesar $55,7 \mathrm{~km} / 1$ dengan nilai efisiensi sebesar $42 \%$. Nilai tersebut lebih tinggi dibandingkan aplikasi pada mesin motor bebek jenis manual $110 \mathrm{cc}$, yaitu pada naphthalene 9 gram/L memberikan nilai konsumsi premium sebesar $48,75 \mathrm{~km} / \mathrm{L}$ dengan nilai efisiensi sebesar $25 \%$. Akan tetapi penambahan Napthalene tetap memberikan pengaruh positif terhadap tingkat presentase efisiensi penggunaan premium sebagai bahan bakar.

Napthalene sebagai zat aditif berperan dalam menaikkan bilangan oktan pada premium. Bilangan oktan sangat berpengaruh terhadap kinerja suatu bahan bakar. Penggunaan bahan bakar dengan nilai oktan yang sesuai akan membuat kerja mesin lebih bertenaga dan konsumsi bahan bakar menjadi lebih irit [13]. Selain itu, dengan naiknya bilangan oktan akan berpengaruh pada proses pembakaran yang lebih cepat dan terhindar dari letupan (knocking). Sifat dari struktur kimia Napthalene yang bersifat aromatik membuat Napthalene mempunyai sifat anti-knocking yang baik. Oleh sebab itu penambahan Naphtalene pada bensin akan meningkatkan mutu anti-knocking dari bensin sehingga konsumsi bensin menjadi lebih irit [13].

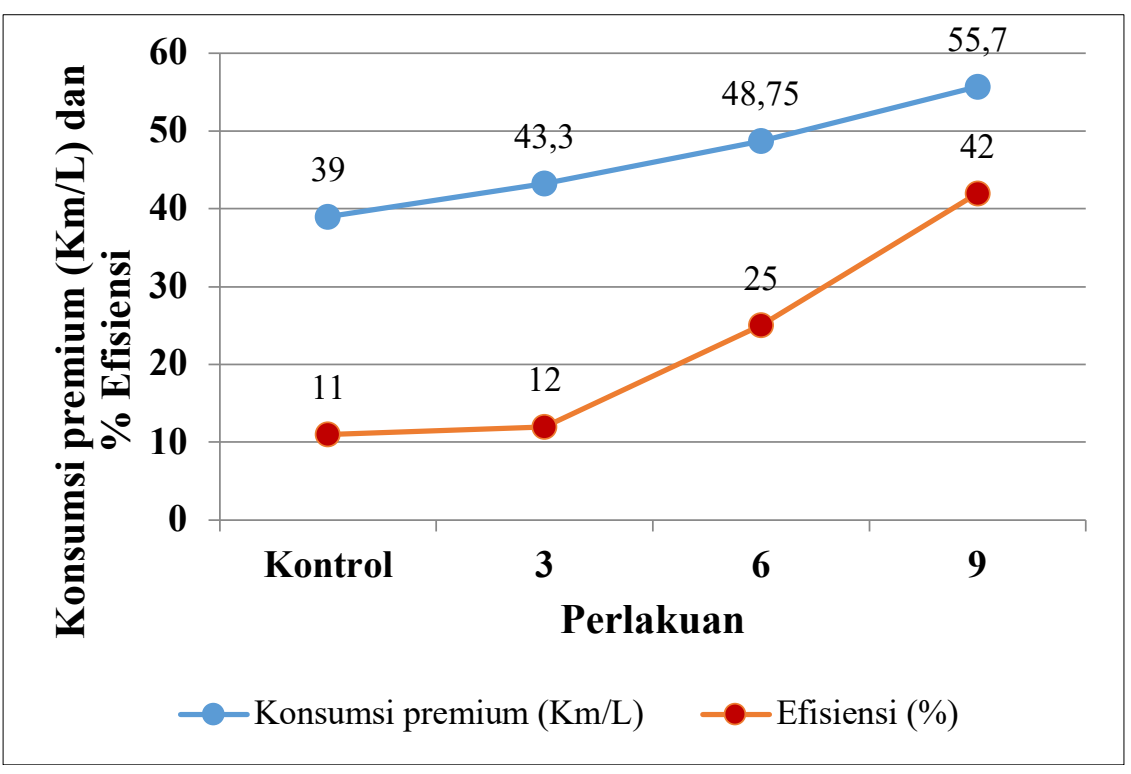

Gambar 5. Persentase efisiensi konsumsi bahan bakar premium pada sepeda motor bebek 4tak jenis manual $115 \mathrm{cc}$

Rekayasa Hijau - 120 
Selain dilakukan pengujian terhadap nilai konsumsi dan efisiensi bahan bakar, dilakukan juga pengujian untuk menganalisis pengaruh rasio pengunaan Napthalene terhadap persentase peningkatan kinerja mesin sepeda motor bebek 4tak jenis manual $110 \mathrm{cc}$ dan sepeda motor bebek 4 tak jenis manual $115 \mathrm{cc}$. Dari tabel 3 pengaruh rasio Naphthalene terhadap kinerja mesin pada sepeda motor bebek 4tak jenis manual 110 cc dapat dilihat bahwa pada perlakuan kontrol rasio perbandingan Napthalene menghasilkan daya kuda sebesar $6,00 \mathrm{hp}$ dan torsi sebesar 4,85 Nm. Dan pada perlakuan rasio perbandingan Naphthalene sebanyak 3 gram/L menghasilkan daya kuda sebesar 6,01 hp dan torsi sebesar 4,89 Nm. Selanjutnya pada perlakuan rasio perbandingan Napthalene sebanyak 6 gram/L menghasilkan daya kuda sebesar 6,11 hp dan torsi sebesar 4,97 Nm. Sedangkan pada perlakuan rasio perbandingan Napthalene sebanyak 9 gram/L menghasilkan daya kuda sebesar 6,12 hp dan torsi sebesar 5,01 Nm.

Tabel 3. Pengaruh rasio Napthalene terhadap kinerja mesin pada sepeda motor bebek 4tak jenis manual $110 \mathrm{cc}$

\begin{tabular}{ccc}
\hline Perlakuan (gram) & Daya Kuda/horse power(hp) & Torsi/torque $(\mathrm{Nm})$ \\
\hline Kontrol & 6,00 & 4,85 \\
3 & $6,01(0,17 \%)$ & $4,89 \mathrm{Nm}(0,83 \%)$ \\
6 & $6,11(1,9 \%)$ & $4,97 \mathrm{Nm}(2,5 \%)$ \\
9 & $6,12(2,0 \%)$ & $5,01 \mathrm{Nm}(3,30 \%)$ \\
\hline
\end{tabular}

Pengaruh rasio Naphthalene terhadap kinerja mesin pada sepeda motor bebek 4tak jenis manual $115 \mathrm{cc}$ berdasarkan tabel 4 bahwa pada perlakuan kontrol rasio perbandingan Napthalene menghasilkan daya kuda kuda sebesar $6,45 \mathrm{hp}$ dan torsi sebesar 5,00 Nm. Dan pada perlakuan rasio perbandingan Naphthalene sebanyak 3 gram/L menghasilkan daya kuda sebesar 6,48 hp dan torsi sebesar 5,09 Nm. Selanjutnya pada perlakuan rasio perbandingan Napthalene sebanyak 6 gram/L menghasilkan daya kuda sebesar $6,55 \mathrm{hp}$ dan torsi sebesar $5,12 \mathrm{Nm}$. Sedangkan pada perlakuan rasio perbandingan Napthalene sebanyak 9 gram/L menghasilkan daya kuda sebesar $6,58 \mathrm{hp}$ dan torsi sebesar 5,15 Nm.

Tabel 4. Pengaruh rasio Napthalene terrhadap kinerja mesin pada sepeda motor bebek 4tak jenis manual $115 \mathrm{cc}$

\begin{tabular}{ccc}
\hline Perlakuan (gram) & Daya Kuda/horse power $(\mathrm{hp})$ & Torsi/torque $(\mathrm{Nm})$ \\
\hline Kontrol & 6,45 & 5,00 \\
3 & $6,48(0,46 \%)$ & $5,09 \mathrm{Nm}(1,8 \%)$ \\
6 & $6,55(1,55 \%)$ & $5,12 \mathrm{Nm}(2,4 \%)$ \\
9 & $6,58(2,0 \%)$ & $5,15 \mathrm{Nm}(3,0 \%)$ \\
\hline
\end{tabular}

Hasil pengujian pengaruh penggunaan Napthalene terhadap peningkatan tenaga mesin menunjukkan perlakuan rasio Napthalene sebanyak 9 gram/L menghasilkan daya dan torsi terbaik pada sepeda motor bebek 4tak jenis manual $110 \mathrm{cc}$ (Tabel 3). Daya kuda/ horse power yang dihasilkan sebesar 6,12 hp dengan persentase peningkatan $2,0 \%$. Sedangkan untuk Torsi yang dihasilkan pada rasio penambahan Napthalene yang sama yaitu sebesar 5,01 Nm dengan persentase peningkatan sebesar 3,30\%. Rasio penambahan Napthalene pada premium berbanding lurus terhadap peningkatan daya kuda dan torsi yang dihasilkan. Uji kinerja pada mesin sepeda motor bebek 4 tak jenis manual 115 cc menunjukkan hal yang hampir sama. Napthalene dengan rasio $9 \mathrm{gram} / \mathrm{L}$ menghasilkan daya kuda dan torsi terbaik (Tabel 4). Daya kuda/ horse power yang dihasilkan sebesar $6,58 \mathrm{hp}$ dengan persentase peningkatan $2,0 \%$. Sedangkan untuk Torsi yang dihasilkan pada rasio penambahan Napthalene yang sama yaitu sebesar $5,15 \mathrm{Nm}$ dengan persentase peningkatan sebesar 3,0\%. Selain berfungsi dalam menghemat penggunaan premium sebagai bahan bakar. Struktur kimia Napthalene yang berbentuk cincin benzena selain dapat memberikan efek efisiensi dalam penggunaan bahan bakar dalam hal ini premium [13] [14]. Napthalene dapat meningkatkan daya kuda dan torsi yang dihasilkan mesin bensin ataupun diesel [15]. Beberapa 
kajian dari peneliti dan jurnal lain juga mengungkapkan bahwa terjadi kenaikan daya rata-rata $8 \%$ dan torsi rata-rata sebesar $10 \%[16]$.

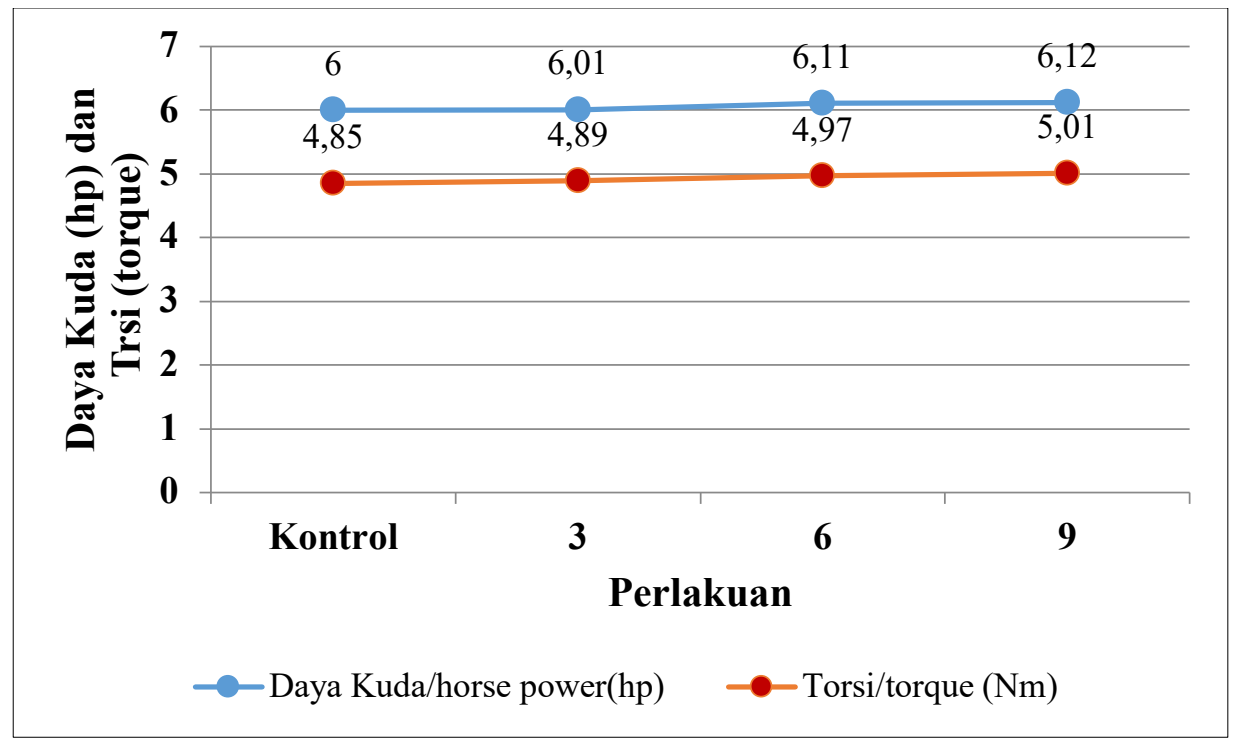

Gambar 6. Pengaruh rasio Napthalene terhadap kinerja mesin pada sepeda motor bebek 4tak jenis manual 110 cc

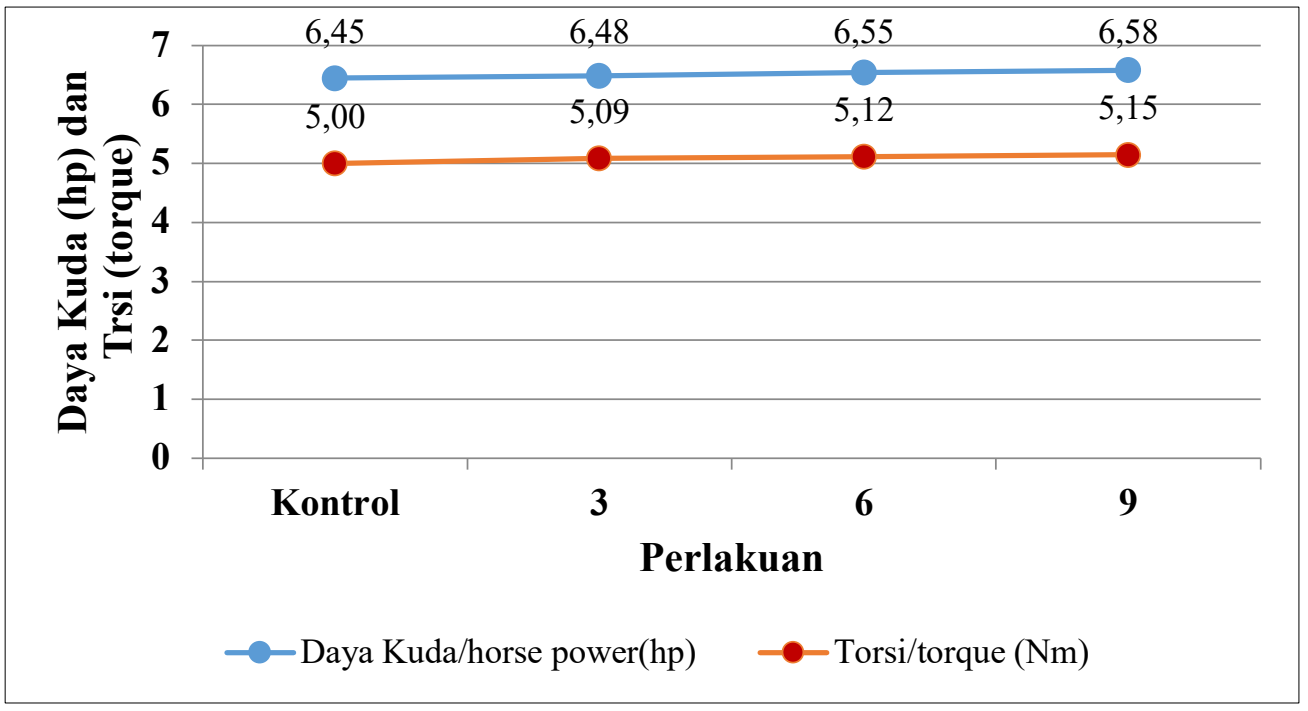

Gambar 7. Pengaruh rasio Napthalene terrhadap kinerja mesin pada sepeda motor bebek 4tak jenis manual $115 \mathrm{cc}$

\section{KESIMPULAN}

Mencampurkan Napthalene pada bahan bakar premium berpengaruh terhadap persentase efisiensi konsumsi premium sebagai bahan bakar. Selain itu, berpengaruh juga terhadap peningkatan kinerja mesin. Rasio pencampuran Napthalene pada bahan bakar premium sebanyak 9 gram/l merupakan rasio terbaik dalam meningkatkan persentase efisiensi konsumsi premium sebagai bahan bakar serta peningkatan kinerja mesin baik pada sepeda motor bebek 4tak jenis manual $110 \mathrm{cc}$ atau sepeda motor bebek 4 tak jenis manual $115 \mathrm{cc}$. Peningkatan nilai efisiensi konsumsi bahan bakar premium pada sepeda motor bebek 4 tak jenis manual $110 \mathrm{cc}$ sebesar $25 \%$ dengan persentase peningkatan torsi yang dihasilnya 
sebesar 3,30\% dan daya kuda (Horse Power) sebesar $2 \%$. Sedangkan peningkatan nilai efisiensi konsumsi bahan bakar premium pada sepeda motor bebek 4tak jenis manual 115 cc sebesar $42 \%$ dengan peningkatan torsi yang dihasilnya sebesar 3,0\% dan daya kuda (Horse Power) sebesar $2 \%$. Penambahan Napthalene pada bahan bakar premium dapat diaplikasikan pada sepeda motor bebek 4tak jenis manual 110 cc maupun pada sepeda motor bebek 4tak jenis manual 115 cc untuk meningkatkan efisiensi konsumsi bahan bakar serta peningkatan kinerja mesin. Dimana dari peningkatan kinerja mesin akan menghasilkan kualitas gas buang kendaraan menjadi lebih baik.

\section{UCAPAN TERIMA KASIH}

Kami ucapkan terima kasih kepada Program Studi Teknik Mesin, Fakultas Teknologi Industri Universitas Jayabaya Jakarta dan PT. Tri Mentari Niaga Sentul Bogor atas izin serta dukungan fasilitas yang diberikan, sehingga penelitian ini dapat terselesaikan.

\section{DAFTAR RUJUKAN}

[1] BPS. 2018. Perkembangan Jumlah Kendaraan Bermotor Menurut Jenis, 1949-2018. https://www.bps.go.id/linkTableDinamis/view/id/1133 [26 Oktober 2020].

[2] PPDN, Direktorat. 2012. Kutipan Spesifikasi Dirjen Migas ; Bahan Bakar Minyak, Bahan Bakar Khusus, bahan bakar Gas Elpiji, dan lampiran. Pertamina. Jakarta.

[3] Kementerian Energi dan Sumber Daya Mineral Republik Indonesia Direktorat Jenderal Minyak dan Gas Bumi. 2013. Surat Keputusan Direktur Jenderal Minyak dan Gas Bumi Nomor. 313.k/10/djm.t/2013 tentang Standar dan Mutu (spesifikasi) bahan bakar minyak jenis bensin 90 yang dipasarkan dalam negeri.

[4] Ginting, T. 2013. Analisa Pengaruh Campuran Premium Dengan Kapur Barus (Napthalen) Terhadap Emisi Gas Buang Pada Mesin Supra X 125 CC. Akademi Teknologi Industri Immanuel Medan.

[5] Tri Hartono, Subroto, dan Nur Aklis, 2011. Penelitian Pengaruh Penggunaan Bahan Bakar Premium, Pertamax dan Pertamax Plus Terhadap Unjuk Kerja Motor Bakar Bensin. Jurusan Teknik Mesin Fakultas Teknik Universitas Muhammadiyah Surakarta.

[6] Lukman Hakim. 2004. Pengaruh Penggunaan Berbagai Jenis Bahan Bakar (Premium, Pertamax, Pertamax Plus) Terhadap Unjuk Kerja Motor Bensin 4 Langkah (4-tak). Undergraduate Theses from JIPTUMMPP, Engineering, Malang

[7] Tirtoatmodjo, Rahardjo. 2001. Pengaruh Naphthalene Terhadap Perubahan Angka Oktan Bensin Unjuk Kerja Dan Gas Buangnya. Jurusan Teknik Mesin Universitas Kristen Petra.

[8] Ruspandi, Sondra. 2015. Kajian Eksperimental Unjuk Kerja Motor Bakar Bensin Berbahan Bakar Pertalite Dengan Campuran Kapur Barus. Program Studi Teknik Mesin Universitas Bung Hatta.

[9] Kabib, Masruki. 2009. Pengaruh Pemakaian Campuran Premium Dengan Camphor Terhadap Perfomansi Dan Emisi Gas Buang Mesin bensin toyota Kijang Seri 4K. Fakultas Teknik Universitas Maria Kudus.

[10] Erdianto, Rahmat. 2013. Penggunaan CDI Digital Hyper Band dan Pemakaian Campuran Premium Dengan Camphor Terhadap Emisi Gas Buang Pada Sepeda Motor Yamaha Jupiter Mx Tahun 2012. Prodi Pendidikan Teknik Mesin Universitas Sebelas Maret.

[11] Arismunandar, Wiranto. 2005. Penggerak Mula Motor Bakar Torak. Penerbit ITB : Bandung

[12] Jama, Jalius. 2008. Teknik Sepeda Motor. Semarang : Aneka Ilmu.

[13] Wahyu Eko Saputra, Harmen Burhanuddin, M. Dyan Susila, 2013, "Pengaruh Penambahan Zat Aditif Alami Pada Bensin Terhadap Prestasi Sepeda Motor 4-Langkah", JURNAL FEMA, Jurnal Ilmiah Teknik Mesin, Volume 1, Nomor 1, Januari 2013, Universitas Lampung, Bandar Lampung.

[14] Najamudin. 2018. Analisa Pengaruh Penambahan Zat Aditif Alami Pada Bensin Terhadap Emisi Gas Buang Untuk Sepeda Motor 4 Langkah. Machine; Jurnal Teknik Mesin Vol. 4 No. 1, Januari 2018. 
[15] Filter, Sehat Abdi Saragih. 2020. Analisa Pengaruh Campuran Bahan Bakar Pertalite dengan Naftalena Terhadap Unjuk Kerja dan Emisi Gas Buang pada Mesin Sepeda Motor. Journal REM (Renewable Energy and Mechanics) Vol.03 No.01 2020: 6-21, Universitas Islam Riau.

[16] I.K. Suka Arimbawa, I.N. Pasek Nugraha, K. RihendraDantes, 2019. "Analisis Pengaruh Campuran Bahan Bakar Pertalite dengan Naphthalene Terhadap Konsumsi Bahan Bakar, Torsi dan Daya Pada Sepeda Motor 4 Langkah". Jurnal Pendidikan Teknik Mesin Undiksha Vol.7 No. 1, Maret 2019. 